\title{
EFEKTIVITAS MODEL PEMBELAJARAN KOOPERATIF TIPE PAIR CHECKS TERHADAP PRESTASI BELAJAR SISWA SMA NEGERI 1 JELIMPO KABUPATEN LANDAK
}

\author{
Siti Suprihatiningsih \\ Pendididkan Matematika STKIP Pamane Talino \\ ssningsih.math@gmail.com
}

\begin{abstract}
Abstrak
Rendahnya prestasi belajar matematika merupakan salah satu permasalahan yang sulit untuk diselesaikan. Banyak faktor yang berhubungan dengan permasalahana tersebut, salah satunya adalah penggunaan metode pembelajaran yang tepat dalam pembelajaran. Tujuan penelitian ini adalah untuk mengetahui efektivitas pembalajaran matematika menggunakan metode pairs checks terhadap prestasi belajar matematika. metode yang digunakan daam penelitian ini adalah metode kuantitatif dengan studi komparasi, dengan uji prasyarat analisis uji normalitas dan uji homogenitas dan uji hipotesis menggunakan uji-t. Hasil penelitian menunjukan bahwa model pembelajaran kooperatif tipe pair checks lebih efektif dibandingkan model pembelajaran langsung terhadap prestasi belajar dapat dilihat dari nilai rata-rata nilai siswa yang diajarkan menggunakan bahwa model pembelajaran kooperatif tipe pair checks yaitu 73,50 sedangkan siswa yang diajarkan dengan model pembelajaran langsung nilai rata-ratanya 54,18. Hal itu diperkuat dengan pengujian hipotesis berdasarkan perbandingan $t_{\text {hitung }}$ dengan $t_{1-\alpha}$ pada taraf signifikan $5 \%$ atau $\alpha=0,05$ menunjukan bahwa $t_{\text {hitung }}$ lebih besar dari $t_{1-\alpha}(1,731585>$ 1,67022).
\end{abstract}

Kata Kunci: metode, pair checks, matematika.

\begin{abstract}
The low level of mathematics learning achievement is one of the problems that is difficult to solve. Many factors are related to these problems, one of which is the use of appropriate learning methods in learning. The purpose of this study is to determine the effectiveness of mathematics learning using the pairs checks method on mathematics learning achievement. The method used in this study is a quantitative method with comparative studies, with a prerequisite test of the analysis of the normality test and homogeneity test and hypothesis testing using the t-test. The results showed that the pairing type cooperative learning model was more effective than the direct learning model of learning achievement, it can be seen from the average value of students who were taught using the pair checks type cooperative learning model that is 73.50 while students who were taught with direct learning models has the average value which is 54.18 . This is reinforced by the hypothesis testing based on the ratio t_count to $t_{-}(1-\alpha)$ at a significant level of $5 \%$ or $\alpha=0.05$ indicating that $t$ _count is greater than $t_{-}(1-\alpha)(1.731585>1.67022)$.
\end{abstract}

Keywords: methods, pair checks, mathematics.

\section{PENDAHULUAN}

Pembelajaran matematika merupakan salah satu komponen dari serangkaian mata pelajaran yang mempunyai peranan penting dalam pendidikan. Matematika merupakan salah satu bidang studi yang mendukung perkembangan ilmu pengetahuan dan teknologi. Namun sampai saat ini masih banyak siswa yang merasa matematika sebagai mata pelajaran yang sulit, tidak menyenangkan, bahkan momok yang menakutkan. Hal ini dikarenakan masih banyak siswa yang menggalami kesulitankesulitan dalam mengerjakan soal-soal matematika (Sundayana, 2013:2).

Berdasarkan hasil observasi dan wawancara yang dilakukan di SMA Negeri 1 Jelimpo khususnya pada kelas $\mathrm{X}$ masih banyak ditemukan permasalahan mengenai kesulitan siswa dalam memahami konsep matematika dalam mengerjakan soal-soal yang guru berikan dilihat hasil nilai ulangan harian siswa yang rata-rata memperoleh nilai 40 dan belum mencapai nilai kriteria 
ketuntasan minimum. Hal tersebut menunjukan rendahnya prestasi belajar siswa pada pelajaran matematika.

Prestasi belajar menurut Hamdani (2011:138) adalah hasil pengukuran dari penilaian usaha belajar yang dinyatakan dalam bentuk simbol, huruf maupun kalimat yang menceritakan hasil yang sudah dicapai oleh setiap anak pada periode tertentu. Suatu metode pembelajaran yang dapat digunakan mempengaruhi prestasi belajar siswa dalam pembelajaran matematika, yaitu metode pembelajaran metode Pair Checks.

Menurut Kurniasih dan Sani (2017:111), model pembelajaran kooperatif tipe Pair Checks dipopulerkan oleh Spencer Kagen jika diterjemahkan bebas Pair Checks artinya "pasangan mengecek". Metode pembelajaran Pair Checks ini adalah proses belajar yang mengedepankan kerja sama kelompok, dimana setiap anggota harus memiliki kemampuan dalam menyelesaikan persoalan yang diberikan. Selanjutnya Model pembelajaran kooperatif tipe Pair Checks adalah metode pembelajaran di mana siswa saling berpasangan dan menyelesaikan persoalan yang diberikan (Herdian dalam Shoimin, 2013:119).

Menurut Huda (2015:211), metode pembelajaran Pair Checks merupakan metode pembelajaran berkelompok antardua orang atau berpasangan. Metode ini menerapkan pembelajaran kooperatif yang menuntut kemandirian dan kemampuan siswa dalam menyelesaikan persoalan. Metode ini juga melatih tanggung jawab sosial siswa, kerjasama dan kemampuan memberi penilaian.

Adapun langkah-langkah Langkahlangkah metode pembelajaran menurut Darmadi (2017:59), yaitu bekerja berpasangan. Guru membentuk tim berpasangan 2 (dua) peserta didik. Setiap pasangan mengerjakan soal yang pas sebab semua itu akan membantu melatih, pelatih mengecek. Apabila patner benar pelatih memberi kupon, bertukar peran. Seluruh patner bertukar peran dan mengulangi langkah 1-3, pasangan mengecek. Seluruh pasangan tim kembali bersama dan membandingkan jawaban dan penegasan
Guru. Guru mengarahkan jawaban / ide sesuai konsep.

Menurut Kurniasih dan Sani (2017:112), terdapat kekurangan dan kelebihan dalam metode Pair Checks, yaitu, dipandu belajar melalui bantuan rekan, menciptakan saling kerjasama di antara siswa dan meningkatkan pemahaman konsep dan atau proses dan kekurangan metode Pair Checks yaitu memerlukan banyak waktu, memerlukan pemahaman yang tinggi terhadap konsep untuk menjadi pelatih.

Penelitian ini bertujuan untuk mengetahui efektivitas model pembelajaran kooperatif tipe Pair Checks terhadap prestasi belajar siswa SMA Negeri 1 Jelimpo Kabupaten Landak. Diharapakan dengan dilakukannya penelitian ini dapat bermanfaat dan mampu mengembangkan ilmu pendidikan agar lebih baik lagi khususnya masalah yang berkaitan dengan prestasi belajar siswa.

\section{METODE}

Penelitian ini dilaksanakan di SMA Negeri 1 Jelimpo Kecamatan Jelimpo Kabupaten Landak. Waktu pelaksanaan dilaksanakan pada tanggal 10-24 November 2018. Penelitian ini menggunakan penelitian kuantitatif dengan metode komparasi. Populasi pada penelitian ini adalah siswa kelas $\mathrm{X}$ SMA Negeri 1 Jelimpo. Sampel dalam penelitian ini adalah kelas X IIS A dan X IIS B. Teknik pengambilan sampel yaitu Cluster Random Sampling.

Teknik pengumpulan data dilakukan dengan menggunakan tes prestasi belajar pada materi sistem persamaan dan pertidaksamaan linear. Jumlah soal tes yang diujicobakan berjumlah 30 butir soal dalam bentuk pilihan ganda yang diujicobakan.

Uji instrumen tes yang dilakukan yaitu uji validitas isi yang diuji oleh 3 orang validator, terdiri dari dua orang guru matematika SMA Negeri 1 Jelimpo dan satu orang dosen Pendidikan Matematika. Uji reliabilitas menggunakan rumus Alpha dengan indeks $r_{11} \geq 0,70$. Tingkat kesukaran yang digunakan yaitu berkriteria sedang antara 0,31-0,70. Sedangkan untuk daya beda antara 0,41-0,70 berkeriteria baik.

Teknik analisis data terdiri dari uji 
prasyarat meliputi uji normalitas menggunakan metode uji Lilliefors dan uji homogenitas menggunakan uji Bartlett. Kemudian uji hipotesis dengan menggunakan rumus uji-t.

\section{HASIL DAN PEMBAHASAN}

Uji coba instrumen dilaksanakan di SMA Negeri 1 Jelimpo semester ganjil tahun ajaran 2018/2019 pada siswa kelas XI yang telah mendapat pembelajaran persamaan dan pertidaksamaan linear. Berdasarkan hasil uji coba instrumen diperoleh data sebagai berikut.

Validasi dilakukan oleh tiga orang ahli matematika dengan hasil validator pertama diperoleh bahwa instrumen uji coba tes prestasi belajar masih ada soal yang keliru dan harus diperbaiki. Hasil validasi oleh validator kedua bahwa instrumen uji coba tes prestasi belajar dalam pilihan jawaban masih harus diperbaiki dari kecil ke besar atau sebaliknya. Hasil validasi oleh validator ketiga bahwa instrumen uji coba tes prestasi belajar dalam pemilihan kalimat harus sesuai atau tidak memiliki makna ganda.

Hasil uji reliabilitas dengan menggunakan rumus Alpha diperoleh reliabilitas sebesar 0,7362. Karena $r_{11}=$ $0,7362>0,7$ maka instrumen tes prestasi dapat dinyatakan reliabel dan dapat digunakan sebagai instrumen penelitian.

Dari hasil perhitungan tingkat kesukaran dan daya pembeda butir soal tes terhadap 30 butir soal yang diuji cobakan diperoleh data bahwa 25 butir soal yang dapat digunakan sesuai kriteria.

Tabel 1. Tingkat Kesukaran

\begin{tabular}{|c|c|c|}
\hline Kriteria & Nomor Soal & Jumlah \\
\hline Mudah & $1,2,19,24,28,29$ & 6 \\
\hline Sedang & $\begin{array}{c}3,4,6,7,8,9,11,12,13,14, \\
15,18,20,21,22,27,30\end{array}$ & 17 \\
\hline Sukar & $5,10,16,17,23,25,26$ & 7 \\
\hline Total & 30 \\
\hline
\end{tabular}

Tabel 2. Daya Pembeda

\begin{tabular}{|c|c|c|}
\hline Kriteria & Nomor Soal & Jumlah \\
\hline Baik & $6,18,20,21,25,30$ & 6 \\
\hline Cukup & $1,2,3,4,7,8,9,10,11,12,13$, & 19 \\
& $14,15,19,22,23,26,27,29$ & \\
\hline Jelek & $5,16,17,24,28$ & 5 \\
\hline \multicolumn{2}{|c|}{ Total } & 30 \\
\hline
\end{tabular}

analisis pada kelas X IIS A diperoleh $\mathrm{L}_{\max }$ $0,114<\mathrm{L}_{\text {tabel }} 0,144$ disimpulkan sampel berdistribusi normal, kemudian pada kelas X IIS B diperoleh $\mathrm{L}_{\max } 0,089<\mathrm{L}_{\text {tabel }} 0,144$ sehingga dapat disimpulkan sampel berdistribusi normal.

Tabel 3. Uji Normalitas

\begin{tabular}{|l|l|l|l|}
\hline No & $\boldsymbol{L}_{\text {max }}$ & $\boldsymbol{L}_{\text {tabel }}$ & Kesimpulan \\
\hline 1 & 0,114 & 0,144 & $\begin{array}{l}\text { Data } \\
\text { berdistribusi } \\
\text { normal }\end{array}$ \\
\hline 2 & 0,089 & 0,144 & $\begin{array}{l}\text { Data } \\
\text { berdistribusi } \\
\text { normal }\end{array}$ \\
\hline
\end{tabular}

Pada uji homogenitas diperoleh $\boldsymbol{\chi}^{2}$ hitung $=0,309<\boldsymbol{\chi}_{\text {tabel }}^{2}=3,841$ sehingga dapat disimpulkan sampel berasal dari populasi yang homogen.

Tabel 4. Uji Homogenitas

\begin{tabular}{|l|c|c|}
\hline$\chi_{\text {hitung }}^{2}$ & $\chi_{\text {tabel }}^{2}$ & Kesimpulan \\
\hline 0,309 & 3,841 & $\begin{array}{c}\text { Kedua Varians } \\
\text { Homogen }\end{array}$ \\
\hline
\end{tabular}

Syarat untuk melakukan uji hipotesis adalah data harus berdistribusi normal dan homogen. Berdasarkan hasil pengujian normalitas dan pengujian homogenitas pada prestasi belajar siswa pada materi persamaan dan pertidaksamaan linear di peroleh hasil kelas eksperimen dan kelas kontrol setelah diberikan perlakuan yang berbeda menunjukkan bahwa data berdistribusi normal dan homogen, sehingga syarat untuk pengujian hipotesis sudah terpenuhi.

Hasil uji analisis data dengan menggunakan uji $\mathrm{t}$ diperoleh $\mathrm{t}_{\text {hitung }}=$ 1,731585 dan $\frac{t_{0.05} ; 2 ; 61}{2}=1,67022$, dengan daerah kritisnya adalah DK= $\{t \mid t>1,67022\}$. Karena $t_{\text {tabel }}=1,67022$ $\in \mathrm{DK}$ maka dapat disimpulkan $\mathrm{H}_{0}$ ditolak yang berarti model pembelajaran kooperatif tipe pair checks lebih efektif dibandingkan menggunakan model pembelajaran langsung terhadap prestasi belajar siswa SMA Negeri 1 Jelimpo. 
Tabel 5. Uji Hipotesis

\begin{tabular}{|c|c|c|}
\hline $\boldsymbol{t}_{\text {hitung }}$ & $\boldsymbol{t}_{\text {tabel }}$ & Kesimpulan \\
\hline 1,731585 & 1,67022 & $H_{o}$ ditolak \\
\hline
\end{tabular}

Hasil ini diperkuat dengan penelitian yang dilakukan oleh Irawati, Nanik (2009) dengan judul pengaruh pembelajaran matematika dengan menggunakan metode pair checks terhadap prestasi belajar (pada siswa kelas VII SMP muhammadiyah 4 surakarta) menyimpulkan bahwa hasil pengujian hipotesis menggunakan $\% 5=\alpha$ menunjukkan thit $=$ 3,285 dimana thit $>\mathrm{t}(0.05: 72)=1,993$ sehingga hipotesis $\mathrm{HO}$ ditolak yang berarti ada perbedaan prestasi belajar matematika yang dipengaruhi oleh penggunaan model pembelajaran kooperatif tipe Pair Checks dan metode konvensional dalam kegiatan belajar mengajar matematika. Lebih lanjut dikatakan bahwa prestasi belajar matematika dengan menggunakan metode pembelajaran Pair Checks lebih baik

\section{DAFTAR PUSTAKA}

Darmadi. 2017. Pengembangan Model dan Metode Pembelajaran Dalam Dinamika Belajar Siswa. Yogyakarta: Deepublish.

Hamdani. 2011. Strategi Belajar Mengajar. Bandung : Pustaka Setia.

Huda, Miftahul. 2015. Model-model Pengajaran dan Pembelajaran. Yogyakarta: Pustaka Pelajar.

Kurniasih, Imas dan Sani, Berlin. 2017. Ragam Pengembanagn Model Pembelajaran. Surabaya. Kata Pena.

Shoimin, Aris. 2014. 68 Model Pembelajaran Inovatif Dalam daripada prestasi belajar matematika dengan menggunakan metode pembelajaran konvensional.

\section{SIMPULAN}

Berdasarkan hasil pembahasan dan penelitian di SMA Negeri 1 Jelimpo dan pengolahan data sehingga dapat diambil kesimpulan bahwa model pembelajaran kooperatif tipe pair checks lebih efektif dibandingkan model pembelajaran langsung terhadap prestasi belajar dapat dilihat dari nilai rata-rata nilai siswa yang diajarkan menggunakan bahwa model pembelajaran kooperatif tipe pair checks yaitu 73,50 sedangkan siswa yang diajarkan dengan model pembelajaran langsung nilai rataratanya 54,18. Hal itu diperkuat dengan pengujian hipotesis berdasarkan perbandingan $t_{\text {hitung }}$ dengan $t_{1-\alpha}$ pada taraf signifikan $5 \%$ atau $\alpha=0,05$ menunjukan bahwa $t_{\text {hitung }}$ lebih besar dari $t_{1-\alpha}(1,731585>1,67022)$.

Kurikulum 2013. Yogyakarta: Ar. Ruzz Media.

Sundayana, Rostina. 2013. Media Pembelajaran Matematika (untuk guru, calon guru, orang tua, dan para pecinta matematika). Bandung: Alfabeta.

Irawati, nanik. 2009. Pengaruh pembelajaran matematika dengan menggunakan metode pair checks terhadap prestasi belajar ( pada siswa kelas vii smp muhammadiyah 4 surakarta). Universitas Muhammadiyah Surakarta. Skripsi. 